\title{
DESIGN AND SYNTHESIS OF BENZODIAZEPINES BEARING BENZIMIDAZOLE/BENZOTHIAZOLE AND INDOLE MOIETIES AS A POTENT ANTIMICROBIAL AND ANTIOXIDANT AGENTS
}

\author{
BASAVARAJ SHIVABASAPPA NARABOLI, BIRADAR JS* \\ Department of Postgraduate Studies and Research in Chemistry, Gulbarga University, Kalaburagi, Karnataka, India. \\ Email: jsbiradar@rediffmail.com
}

Received: 10 August 2017, Received and Accepted: 27 September 2017

\section{ABSTRACT}

Objective: The present work deals with the synthesis and characterization of biologically active new indole derivatives, namely, 2-((1H-benzo[d] imidazol-2-yl) thio)- $N$-(4-(4-(1H-indol-3-yl)-8-methyl- $1 H$-benzo[b][1,4]diazepin-2-yl) phenyl) acetamide 3a-d, $N$-(4-(4-(1H-indol-3-yl)-8-methyl$1 H$-benzo[b][1,4]diazepin-2-yl) phenyl)-2-((5-methoxy-1H-benzo[d]imidazol-2-yl) thio) acetamide 4a-d and $N$-(4-(4-(1H-indol-3-yl)-8-methyl-1Hbenzo[b][1,4]diazepin-2-yl) phenyl)-2-(benzo[d]thiazol-2-ylthio) acetamide 5a-d.

Methods: All these newly synthesized compounds were screened for their in vitro antimicrobial activity by an agar plate diffusion method, antioxidant activities such as 1,1-diphenyl-2-picrylhydrazyl (DPPH), radical scavenging activity (RSA), ferric ions $\left(\mathrm{Fe}^{3+}\right)$ reducing antioxidant power (FRAP), and ferrous $\left(\mathrm{Fe}^{2+}\right)$ metal ion chelating activity.

Result: The structures of all the newly synthesized compounds were characterized by their infrared, ${ }^{1} \mathrm{H}$ nuclear magnetic resonance, mass spectral studies, and elemental analysis. Compounds 7a and 7b exhibited good RSA at a concentration $100 \mu \mathrm{g} / \mathrm{ml}$, compounds $6 \mathrm{~d}$, 7a-d and 8a-c displayed good FRAP at a concentration $100 \mu \mathrm{g} / \mathrm{ml}$, compounds $7 \mathrm{~b}-\mathrm{d}$ and $8 \mathrm{~b}-\mathrm{d}$ showed good Fe ${ }^{2+}$ ion metal chelating activity. Compounds 6b, 6d, 7a-d, and 8a-d exhibited good activity against all the screened bacteria and fungi.

Conclusion: Some of the compounds have shown potent antimicrobial activity against all the screened bacteria and fungi, and some have exhibited very good antioxidant activity.

Keywords: Benzodiazepine, Indole, Benzimidazole/Benzothiazole, Antimicrobial, Antioxidant.

(c) 2018 The Authors. Published by Innovare Academic Sciences Pvt Ltd. This is an open access article under the CC BY license (http://creativecommons. org/licenses/by/4. 0/) DOI: http://dx.doi.org/10.22159/ajpcr.2018.v11i1.21947

\section{INTRODUCTION}

Benzodiazepines and their derivatives are a very important class of bioactive compounds because of their diverse pharmacological properties. They are widely used as antidepressants, anticonvulsant, analgesic, hypnotic, and sedative [1]. This compound possesses antiinflammatory [2], antimicrobial, antioxidant [3], and anticancer activity [4]. It acts as an inhibitor of respiratory syncytial virus [5]. 1, 4-benzodiazepine analogs have been demonstrated as anticonvulsants, muscle relaxants, blood pressure lowering, and CNS depressant agents [6].

Alongside, indole and its biheterocycles are featured widely in a wide variety of biological and pharmacologically active compounds [7]. The indole derivatives are known to possess anticancer, antioxidant, antitumor, and anti-HIV [8-11, 28] activities.

Benzimidazole is an essential pharmacophore and a privileged structure in medicinal chemistry. It has been found to possess antioxidant, anti-inflammatory, diuretic, antiviral, anticonvulsant, and antidiabetic [12-17] activities.

Benzothiazole is also a heterocyclic compound, with various biological activities. This heterocycle possess diverse biological activities such as antitumor, anticancer, antifungal and antibacterial, and antidiabetic [18-22] activities.

In the view of above-mentioned facts, we describe herein the design, synthesis, and characterization of some benzodiazepines bearing benzimidazole/benzothiazole and indole moieties as a potent antimicrobial and antioxidant agents.

\section{MATERIALS AND METHODS}

\section{Materials}

All chemicals and solvents were of commercial reagent grade and used as received from Sigma-Aldrich and Spectrochem Pvt., Ltd. Melting points were determined in open capillaries and are uncorrected. The purity of the compounds was checked by TLC using silica gel-G coated aluminum plates (Merck), and spots were visualized by exposing the dry plates to iodine vapors. The infrared (IR) (KBr) spectra were recorded on a Perkin-Elmer spectrum one FT-IR spectrometer. The ${ }^{1} \mathrm{H}$ nuclear magnetic resonance (NMR) dimethyl sulfoxide (DMSO- $d_{6}$ ) spectra recorded on a Bruker NMR $(400 \mathrm{MHz})$ and the chemical shifts were expressed in ppm ( $\delta$ scale) downfield from TMS. Mass spectral data were recorded by electron impact method on JEOL GCMATE II GCMS mass spectrometer. Elemental analysis was performed using Flash EA 1112 series elemental analyzer. All the compounds gave $\mathrm{C}, \mathrm{H}$, and $\mathrm{N}$ analysis within $\pm 0.5 \%$ of the theoretical values.

General procedure for the synthesis of $N$-(4-acetylphenyl)-2chloroacetamide (2) was prepared by following the literature method [23].

General procedure for the synthesis of 2-(1H-benzo[d]imidazole2-ylthio) $\quad N$-(4-acetylphenyl) acetamide, $N$-(4-acetylphenyl)-2-((5methoxy- $1 H$-benzo[d]imidazol-2-yl)thio) acetamide and $N$-(4acetylphenyl)-2-(benzo[d]thiazol-2-ylthio) acetamide (3, 4, and 5) was prepared by following the literature method [23]. 
$\mathrm{N}$-(4-acetylphenyl)-2-chloroacetamide (2) (0.01 mol) obtained was further reacted with 2-mercatobenzimidazole, 2-mercapto-5-methoxy benzimidazole and 2-mercapto benzothiazole $(0.01 \mathrm{~mol})$. The reaction was stirred for $4 \mathrm{~h}$ at room temperature in the presence of $\mathrm{K}_{2} \mathrm{CO}_{3} 0.02$ $\mathrm{mol})$ and acetone $(20 \mathrm{ml})$ was used as the reaction medium. After the completion of the reaction, it was monitored on TLC using Toluene: Acetone (8:2) as mobile phase, the product obtained was poured into water and stirred vigorously for $1 \mathrm{~h}$. The separated precipitate was collected and dried. The product was recrystallized from ethanol.

2-(1H-benzo[d]imidazole-2-ylthio) $\mathbf{N}$-(4-acetylphenyl) acetamide (3) Yield $86 \%$ (Ethanol); M.P $210^{\circ} \mathrm{C}$; IR (KBr) $\left(\lambda_{\text {max }}\right.$ in $\left.\mathrm{cm}^{-1}\right): 1409,1650$, 2850, 3110, 3285, 3400. ${ }^{1} \mathrm{H}$ NMR (DMSO-d $\left.{ }_{6}+\mathrm{CDCl}_{3}\right)^{\delta}(\mathrm{ppm}): 2.50$ $\left(\mathrm{S}, 3 \mathrm{H},-\mathrm{CH}_{3}\right), 4.32\left(\mathrm{~S}, 2 \mathrm{H},-\mathrm{CH}_{2}\right), 7.10-7.96(\mathrm{~m}, 8 \mathrm{H}, \mathrm{Ar}-\mathrm{H}), 10.85(\mathrm{~S}, 1 \mathrm{H}$, -NH), $12.86\left(\mathrm{~S}, 1 \mathrm{H}\right.$, benzimidazole -NH). Anal. Calcd for $\mathrm{C}_{17} \mathrm{H}_{15} \mathrm{~N}_{3} \mathrm{O}_{2} \mathrm{~S}$ (325): C, 62.75; H, 4.65; N, 12.91. Found: C, 62.74; H, 4.67; N, 12.90.

$N$-(4-acetylphenyl)-2-((5-methoxy- $1 H$-benzo[d]imidazol-2-yl) thio) acetamide (4)

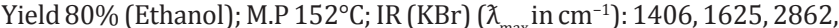
2992, 3285, 3379. ${ }^{1} \mathrm{H}$ NMR (DMSO-d $\left.+\mathrm{CDCl}_{3}\right)^{\delta}(\mathrm{ppm}): 2.50\left(\mathrm{~S}, 3 \mathrm{H},-\mathrm{CH}_{3}\right)$, $3.76\left(\mathrm{~S}, 3 \mathrm{H}, \mathrm{OCH}_{3}\right), 4.32\left(\mathrm{~S}, 2 \mathrm{H},-\mathrm{CH}_{2}\right), 6.72-8.22(\mathrm{~m}, 7 \mathrm{H}, \mathrm{Ar}-\mathrm{H}), 10.88(\mathrm{~S}$, $1 \mathrm{H},-\mathrm{NH}), 12.48(\mathrm{~S}, 1 \mathrm{H}$, benzimidazole $-\mathrm{NH})$. Anal. Calcd for $\mathrm{C}_{18} \mathrm{H}_{17} \mathrm{~N}_{3} \mathrm{O}_{3} \mathrm{~S}$ (355): C, 60.83; H, 4.82; N, 11.82. Found: C, 60.81; H, 4.85; N, 11.81.

N-(4-acetylphenyl)-2-(benzo[d]thiazol-2-ylthio) acetamide (5) Yield $77 \%$ (Ethanol); M.P $130^{\circ} \mathrm{C}$; IR $(\mathrm{KBr})\left(\lambda_{\max }\right.$ in $\left.\mathrm{cm}^{-1}\right): 1457,1625$, 2850, 2992, 3276, 3380. ${ }^{1} \mathrm{H}$ NMR (DMSO- $\left.\mathrm{d}_{6}+\mathrm{CDCl}_{3}\right)^{\delta}(\mathrm{ppm}): 2.50$ (S, $\left.3 \mathrm{H},-\mathrm{CH}_{3}\right), 4.40\left(\mathrm{~S}, 2 \mathrm{H},-\mathrm{CH}_{2}\right), 7.29-7.92(\mathrm{~m}, 8 \mathrm{H}, \mathrm{Ar}-\mathrm{H}), 10.71(\mathrm{~S}, 1 \mathrm{H},-\mathrm{NH})$. Anal. Calcd for $\mathrm{C}_{17} \mathrm{H}_{14} \mathrm{~N}_{2} \mathrm{O}_{2} \mathrm{~S}_{2}$ (342): C, 59.63; H, 4.12; N, 8.18. Found: C, 59.61; H, 4.15; N, 8.19.

2-((1H-benzo[d]imidazol-2-yl) $\quad$ thio)- $N$-(4-(4-(1H-indol-3-yl)-8methyl-1H-benzo[b][1,4]diazepin-2-yl) phenyl) acetamide (6a-d) The Claisen-Schmidt condensation of an equimolar mixture of 2-(1H-benzo[d]imidazol-2-ylthio)- $N$-(4-acetylphenyl) acetamide $(0.01$ mol) and various 2,5-disubstituted indole-3-carboxaldehydes (0.01 $\mathrm{mol})$ were refluxed $(3-4 \mathrm{~h})$ in ethanol $(15-20 \mathrm{ml})$ in the presence of piperidine. After $4 \mathrm{~h}$ substituted ortho-phenylenediamine and a catalytic amount of acetic acid was added to the reaction mixture and was further refluxed (7-8 h). The completion of the reaction was monitored by TLC. The product was poured in ice cold water. The product obtained was filtered and purified by ethanol.

2-((1H-benzo[d]imidazol-2-yl) thio)- $N$-(4-(4-(1H-indol-3-yl)-8methyl-1H-benzo[b][1,4]diazepin-2-yl) phenyl) acetamide (6a)

Yield 70\% (Ethanol); M.P $176-178^{\circ} \mathrm{C}$; IR (KBr) $\left(\lambda_{\max }\right.$ in cm$\left.^{-1}\right): 1673,2838$, 3098, 3110, 3318, 3409; ${ }^{1} \mathrm{H}$ NMR (DMSO-d $\left.6+\mathrm{CDCl}_{3}\right)^{\delta}(\mathrm{ppm}): 2.4(\mathrm{~S}$, $\left.3 \mathrm{H},-\mathrm{CH}_{3}\right), 4.4\left(\mathrm{~S}, 2 \mathrm{H},-\mathrm{CH}_{2}\right), 7.8-8.2(\mathrm{~m}, 18 \mathrm{H}, 17 \mathrm{Ar}-\mathrm{H}$, diazepine $-\mathrm{NH}), 10.1$ $(\mathrm{S}, 1 \mathrm{H}$, indole - $\mathrm{NH}), 11.2(\mathrm{~S}, 1 \mathrm{H},-\mathrm{NH}), 12.27(\mathrm{~S}, 1 \mathrm{H}$, benzimidazole $-\mathrm{NH})$. MS: $\mathrm{m} / \mathrm{z}=554[\mathrm{M}]^{+}$. Anal. Calcd for $\mathrm{C}_{33} \mathrm{H}_{26} \mathrm{~N}_{6} \mathrm{OS}$ (554): C, 71.46; H, 4.72; $\mathrm{N}, 15.15$. Found: C, 71.43; H, 4.69; N, 15.12 .

2-((1H-benzo[d]imidazol-2-yl) thio)- $N$-(4-(4-(5-chloro-2-phenyl$1 H$-indol-3-yl)-8-methyl-1 $H$-benzo[b][1,4]diazepin-2-yl) phenyl) acetamide (6b)

Yield $72 \%$ (Ethanol); M.P $144-146^{\circ} \mathrm{C}$; IR (KBr) $\left(\lambda_{\max }\right.$ in $\left.\mathrm{cm}^{-1}\right): 1685$, 2819, 3112, 3153, 3301, 3397, 769. ${ }^{1} \mathrm{H}$ NMR (DMSO-d ${ }_{6}+\mathrm{CDCl}_{3}$ ) ${ }^{\delta}(\mathrm{ppm}): 2.3\left(\mathrm{~S}, 3 \mathrm{H},-\mathrm{CH}_{3}\right), 4.3\left(\mathrm{~S}, 2 \mathrm{H},-\mathrm{CH}_{2}\right), 7.6-8.00(\mathrm{~m}, 21 \mathrm{H}, 20 \mathrm{Ar}-\mathrm{H}$, diazepine - $\mathrm{NH}), 10.3(\mathrm{~S}, 1 \mathrm{H}$, indole $-\mathrm{NH}), 11.4(\mathrm{~S}, 1 \mathrm{H},-\mathrm{NH}), 12.4(\mathrm{~S}, 1 \mathrm{H}$, benzimidazole -NH). MS: $\mathrm{m} / \mathrm{z}=664[\mathrm{M}]^{+}, 666[\mathrm{M}+2]^{+}(3: 1)$. Anal. Calcd for $\mathrm{C}_{39} \mathrm{H}_{29} \mathrm{ClN}_{6} \mathrm{OS}$ (664): C, 70.42; H, 4.39; N, 12.63. Found: C, 70.46; H, 4.36; N, 12.61 .

2-((1H-benzo[d]imidazol-2-yl) thio)- $N$-(4-(8-methyl-4-(5-methyl2-phenyl-1H-indol-3-yl)-1H-benzo[b][1,4]diazepin-2-yl) phenyl) acetamide (6c)

Yield 69\% (Ethanol); M.P $154-156^{\circ} \mathrm{C}$; IR $(\mathrm{KBr})\left(\lambda_{\max }\right.$ in $\left.\mathrm{cm}^{-1}\right): 1659$, $2810,3026,3099,3298,3393 .{ }^{1} \mathrm{H}$ NMR (DMSO- $\left.\mathrm{d}_{6}+\mathrm{CDCl}_{3}\right)^{\delta}(\mathrm{ppm}): 2.42$
$\left(\mathrm{S}, 3 \mathrm{H},-\mathrm{CH}_{3}\right), 2.6\left(\mathrm{~S}, 3 \mathrm{H},-\mathrm{CH}_{3}\right), 4.41\left(\mathrm{~S}, 2 \mathrm{H},-\mathrm{CH}_{2}\right), 7.4-8.3(\mathrm{~m}, 21 \mathrm{H}, 20 \mathrm{Ar}-$ $\mathrm{H}$, diazepine -NH), 9.97 (S, 1H, indole - $\mathrm{NH}), 10.86(\mathrm{~S}, 1 \mathrm{H},-\mathrm{NH}), 12.10$ (S, $1 \mathrm{H}$, benzimidazole $-\mathrm{NH})$. MS: $\mathrm{m} / \mathrm{z}=644[\mathrm{M}]^{+}$. Anal. Calcd for $\mathrm{C}_{40} \mathrm{H}_{32} \mathrm{~N}_{6} \mathrm{OS}$ (644): C, 74.51; H, 5.00; N, 13.03. Found: C, 74.48; H, 5.03; N, 13.05.

2-((1H-benzo[d]imidazol-2-yl)thio)- $\mathrm{N}$ - (4-(4-(5-bromo- $1 \mathrm{H}$ indol-3-yl)-8-methyl-1H-benzo [b][1,4]diazepin-2-yl) phenyl) acetamide (6d)

Yield 64\% (Ethanol); M.P 210-212 ${ }^{\circ}$; $\left(\lambda_{\max }\right.$ in $\left.\mathrm{cm}^{-1}\right)$ : 1668, 2899, 3079, 3099, 3327, 3417, 783. ${ }^{1} \mathrm{H}$ NMR (DMSO-d $\left.+\mathrm{CDCl}_{3}\right)^{\delta}(\mathrm{ppm})$ : $2.39\left(\mathrm{~S}, 3 \mathrm{H},-\mathrm{CH}_{3}\right), 4.26\left(\mathrm{~S}, 2 \mathrm{H},-\mathrm{CH}_{2}\right), 7.7-8.5(\mathrm{~m}, 17 \mathrm{H}, 16 \mathrm{Ar}-\mathrm{H}$, diazepine - $\mathrm{NH}), 10.4(\mathrm{~S}, 1 \mathrm{H}$, indole $-\mathrm{NH}), 11.1(\mathrm{~S}, 1 \mathrm{H},-\mathrm{NH}), 12.2(\mathrm{~S}, 1 \mathrm{H}$, benzimidazole -NH). MS: $\mathrm{m} / \mathrm{z}=632[\mathrm{M}]^{+}, 634[\mathrm{M}+2]^{+}(1: 1)$. Anal. Calcd for $\mathrm{C}_{33} \mathrm{H}_{25} \mathrm{BrN}_{6} \mathrm{OS}$ (632): C, 62.56; H, 3.98; N, 13.26; Found: C, 62.58; $\mathrm{H}$, 3.96; N, 13.25 .

$N$-(4-(4-(1H-indol-3-yl)-8-methyl-1H-benzo[b] [1,4]diazepin2-yl) phenyl)-2-((5-methoxy-1H-benzo[d]imidazol-2-yl) thio) acetamide (7a-d)

The Claisen-Schmidt condensation of an equimolar mixture of $N$-(4-acetylphenyl)-2-((5-methoxy- $1 H$-benzo[d]imidazol-2-yl) thio) acetamide $(0.01 \mathrm{~mol})$ and various 2,5 -disubstituted indole3 -carboxaldehydes $(0.01 \mathrm{~mol})$ were refluxed $(3-4 \mathrm{~h})$ in ethanol $(15-20 \mathrm{ml})$ in the presence of piperidine. After $4 \mathrm{~h}$ substituted orthophenylenediamine and a catalytic amount of acetic acid was added to the reaction mixture and was further refluxed (7-8 h). The completion of the reaction was monitored by TLC. The product was poured in ice cold water. The product obtained was filtered and purified by ethanol.

$N$-(4-(4-(1H-indol-3-yl)-8-methyl-1H-benzo[b][1,4]diazepin2-yl) phenyl)-2-((5-methoxy-1H-benzo[d]imidazol-2-yl) thio) acetamide (7a)

Yield 67\% (Ethanol); M.P $160-162^{\circ} \mathrm{C}$; IR $(\mathrm{KBr})\left(\lambda_{\text {ix }}\right.$ in cm$\left.^{-1}\right): 1663,2829$, 3091, 3107, 3297, 3384. ${ }^{1} \mathrm{H}$ NMR (DMSO-d $\left.{ }_{6}+\mathrm{CDCl}_{3}\right)^{\delta}(\mathrm{ppm}): 2.42(\mathrm{~S}$, $\left.3 \mathrm{H},-\mathrm{CH}_{3}\right), 3.86\left(\mathrm{~S}, 3 \mathrm{H},-\mathrm{OCH}_{3}\right), 4.2\left(\mathrm{~S}, 2 \mathrm{H},-\mathrm{CH}_{2}\right), 7.5-8.4(\mathrm{~m}, 17 \mathrm{H}, 16 \mathrm{Ar}-\mathrm{H}$, diazepine - $\mathrm{NH}), 10.4$ (S, 1H, indole - $\mathrm{NH}), 11.3(\mathrm{~S}, 1 \mathrm{H},-\mathrm{NH}), 11.99(\mathrm{~S}, 1 \mathrm{H}$, benzimidazole -NH). MS: $\mathrm{m} / \mathrm{z}=584[\mathrm{M}]^{+}$. Anal. Calcd for $\mathrm{C}_{34} \mathrm{H}_{28} \mathrm{~N}_{6} \mathrm{O}_{2} \mathrm{~S}$ (584): C, 69.84; H, 4.83; N, 14.37. Found: C, 69.86; H, 4.80; N, 14.35 .

$N$-(4-(4-(5-chloro-2-phenyl-1H-indol-3-yl)-8-methyl- $1 H$-benzo[b] [1,4]diazepin-2-yl) phenyl)-2-((5-methoxy-1H-benzo[d]imidazol2 -yl) thio) acetamide (7b)

Yield $72 \%$ (Ethanol); M.P $188-190^{\circ} \mathrm{C}$; IR (KBr) $\left(\lambda_{\max }\right.$ in $\left.\mathrm{cm}^{-1}\right): 1693$, $2831,3108,3164,3341,3405,781 .{ }^{1} \mathrm{H}$ NMR $\left(\text { DMSO-d }_{6}+\mathrm{CDCl}_{3}\right)^{\delta}(\mathrm{ppm})$ : $2.42\left(\mathrm{~S}, 3 \mathrm{H},-\mathrm{CH}_{3}\right), 3.91\left(\mathrm{~S}, 3 \mathrm{H},-\mathrm{OCH}_{3}\right), 4.46\left(\mathrm{~S}, 2 \mathrm{H},-\mathrm{CH}_{2}\right), 7.1-8.3(\mathrm{~m}$, $20 \mathrm{H}, 19 \mathrm{Ar}-\mathrm{H}$, diazepine - $\mathrm{NH}), 10.5(\mathrm{~S}, 1 \mathrm{H}$, indole $-\mathrm{NH}), 11.6(\mathrm{~S}, 1 \mathrm{H},-\mathrm{NH})$, $12.2(\mathrm{~S}, 1 \mathrm{H}$, benzimidazole $-\mathrm{NH})$. MS: $\mathrm{m} / \mathrm{z}=694[\mathrm{M}]^{+}, 696[\mathrm{M}+2]^{+}(3: 1)$. Anal. Calcd for $\mathrm{C}_{40} \mathrm{H}_{31} \mathrm{ClN}_{6} \mathrm{O}_{2} \mathrm{~S}(694)$ ): C, 69.10; $\mathrm{H}, 4.49 ; \mathrm{N}, 12.09$. Found: C, 69.13; H, 4.45; N, 12.11 .

2-((5-methoxy-1H-benzo[d]imidazol-2-yl) thio)- $N$-(4-(8-methyl4-(5-methyl-2-phenyl-1H-indol-3-yl)- $1 H$-benzo[b][1,4]diazepin-2yl) phenyl) acetamide (7c)

Yield 76\% (Ethanol); M.P $148-150^{\circ} \mathrm{C}$; $(\mathrm{KBr})\left(\lambda_{\text {in }} \mathrm{cm}^{-1}\right): 1641,2798$, $3031,3317,3291,3389 .{ }^{1} \mathrm{H}$ NMR (DMSO-d $\left.6+\mathrm{CDCl}_{3}\right)^{\delta}(\mathrm{ppm}): 2.41(\mathrm{~S}$, $\left.3 \mathrm{H},-\mathrm{CH}_{3}\right), 2.61\left(\mathrm{~S}, 3 \mathrm{H},-\mathrm{CH}_{3}\right), 3.89\left(\mathrm{~S}, 3 \mathrm{H},-\mathrm{OCH}_{3}\right), 4.13\left(\mathrm{~S}, 2 \mathrm{H},-\mathrm{CH}_{2}\right), 7.1-$ $8.5(\mathrm{~m}, 20 \mathrm{H}, 19 \mathrm{Ar}-\mathrm{H}$, diazepine - $\mathrm{NH}), 10.12(\mathrm{~S}, 1 \mathrm{H}$, indole - $\mathrm{NH}), 10.97$ (S, 1H, -NH), $12.6(\mathrm{~S}, 1 \mathrm{H}$, benzimidazole $-\mathrm{NH})$. MS: $\mathrm{m} / \mathrm{z}=674[\mathrm{M}]^{+}$. Anal. Calcd for $\mathrm{C}_{41} \mathrm{H}_{34} \mathrm{~N}_{6} \mathrm{O}_{2} \mathrm{~S}$ (674): C, 72.97; H, 5.08; N, 12.45. Found: C, 72.95; $\mathrm{H}, 5.02 ; \mathrm{N}, 12.44$.

$N$-(4-(4-(5-bromo- $1 H$-indol-3-yl)-8-methyl-1H-benzo[b] [1,4] diazepin-2-yl) phenyl)-2-((5-methoxy-1H-benzo[d]imidazol-2-yl) thio) acetamide (7d)

Yield 65\% (Ethanol); M.P 188- $190^{\circ} \mathrm{C}$; $\left(\lambda_{\max }\right.$ in $\left.\mathrm{cm}^{-1}\right): 1670,2877,3085$, 3121, 3340, 3427, 774. ${ }^{1} \mathrm{H}$ NMR (DMSO- $\left.\mathrm{d}_{6}+\mathrm{CDCl}_{3}\right)^{\delta}(\mathrm{ppm}): 2.44(\mathrm{~S}$, $\left.3 \mathrm{H},-\mathrm{CH}_{3}\right), 3.89\left(\mathrm{~S}, 3 \mathrm{H},-\mathrm{OCH}_{3}\right), 4.61\left(\mathrm{~S}, 2 \mathrm{H},-\mathrm{CH}_{2}\right), 7.2-8.1(\mathrm{~m}, 16 \mathrm{H}, 15 \mathrm{Ar}-$ $\mathrm{H}$, diazepine - $\mathrm{NH}), 10.55(\mathrm{~S}, 1 \mathrm{H}$, indole - $\mathrm{NH}), 11.32(\mathrm{~S}, 1 \mathrm{H},-\mathrm{NH}), 12.4$ (S, $1 \mathrm{H}$, benzimidazole $-\mathrm{NH})$. MS: $\mathrm{m} / \mathrm{z}=662[\mathrm{M}]^{+}, 664[\mathrm{M}+2]^{+}(1: 1)$. Anal. 
Calcd for $\mathrm{C}_{34} \mathrm{H}_{27} \mathrm{BrN}_{6} \mathrm{O}_{2} \mathrm{~S}$ (662): C, 61.54; $\mathrm{H}, 4.10 ; \mathrm{N}, 12.66$. Found: $\mathrm{C}$, $61.51 ; \mathrm{H}, 4.15 ; \mathrm{N}, 12.64$.

$N$-(4-(4-(1H-indol-3-yl)-8-methyl-1H-benzo[b][1,4]diazepin-2-yl) phenyl)-2-(benzo[d]thiazol -2-ylthio) acetamide (8a-d)

The Claisen-Schmidt condensation of an equimolar mixture of $\mathrm{N}$-(4acetylphenyl)-2-(benzo[d]thiazol-2-ylthio) acetamide $(0.01 \mathrm{~mol})$ and various 2,5-disubstituted indole-3-carboxaldehydes $(0.01 \mathrm{~mol})$ were refluxed (3-4 h) in ethanol $(15-20 \mathrm{ml})$ in the presence of piperidine. After $4 \mathrm{~h}$ substituted ortho-phenylenediamine and a catalytic amount of acetic acid was added to the reaction mixture and was further refluxed (7-8 h). The completion of the reaction was monitored by TLC. The product was poured in ice cold water. The product obtained was filtered and purified by ethanol.

$N$-(4-(4-(1H-indol-3-yl)-8-methyl-1H-benzo[b][1,4]diazepin-2-yl) phenyl)-2-(benzo[d]thiazol-2-ylthio) acetamide (8a)

Yield $70 \%$ (Ethanol); M.P $134-136^{\circ} \mathrm{CIR}(\mathrm{KBr})\left(\lambda_{\text {max }}\right.$ in $\left.\mathrm{cm}^{-1}\right): 1668$, 2813, 3099, 3128, 3398. ${ }^{1} \mathrm{H}$ NMR (DMSO- $\left.{ }_{6}+\mathrm{CDCl}_{3}\right)^{\delta}(\mathrm{ppm}): 2.41(\mathrm{~S}$, $\left.3 \mathrm{H},-\mathrm{CH}_{3}\right), 4.12\left(\mathrm{~S}, 2 \mathrm{H},-\mathrm{CH}_{2}\right), 7.3-8.3(\mathrm{~m}, 18 \mathrm{H}, 17 \mathrm{Ar}-\mathrm{H}$, diazepine $-\mathrm{NH})$, $10.2(\mathrm{~S}, 1 \mathrm{H}$, indole $-\mathrm{NH}), 11.4(\mathrm{~S}, 1 \mathrm{H},-\mathrm{NH}) . \mathrm{MS}: \mathrm{m} / \mathrm{z}=571[\mathrm{M}]^{+}$. Anal. Calcd for $\mathrm{C}_{33} \mathrm{H}_{25} \mathrm{~N}_{5} \mathrm{OS}_{2}$ 571): C, 69.33; $\mathrm{H}, 4.41 ; \mathrm{N}, 12.25$. Found: C, 69.35; $\mathrm{H}, 4.44 ; \mathrm{N}, 12.28$.

2-(benzo[d]thiazol-2-ylthio)- $\mathrm{N}$-(4-(4-(5-chloro-2-phenyl-1 $\mathrm{H}$ indol-3-yl)-8-methyl-1H-benzo[b][1,4]diazepin-2-yl) phenyl) acetamide (8b)

Yield 78\% (Ethanol); M.P $178-180^{\circ} \mathrm{C}$; IR $(\mathrm{KBr})\left(\lambda_{\max }\right.$ in $\left.\mathrm{cm}^{-1}\right): 1671$, 2809, 3102, 3164, 3412, 773. ${ }^{1} \mathrm{H}$ NMR (DMSO-d $\left.{ }_{6}+\mathrm{CDCl}_{3}\right)^{8}(\mathrm{ppm}): 2.44$ $\left(\mathrm{S}, 3 \mathrm{H},-\mathrm{CH}_{3}\right), 4.18\left(\mathrm{~S}, 2 \mathrm{H},-\mathrm{CH}_{2}\right), 7.1-8.1(\mathrm{~m}, 21 \mathrm{H}, 20 \mathrm{Ar}-\mathrm{H}$, diazepine - $\mathrm{NH})$, $10.4(\mathrm{~S}, 1 \mathrm{H}$, indole $-\mathrm{NH}), 11.2(\mathrm{~S}, 1 \mathrm{H},-\mathrm{NH}) . \mathrm{MS}: \mathrm{m} / \mathrm{z}=681[\mathrm{M}]^{+}, 683$ $[\mathrm{M}+2]^{+}(3: 1)$. Anal. Calcd for $\left.\mathrm{C}_{39} \mathrm{H}_{28} \mathrm{ClN}_{5} \mathrm{OS}_{2} 681\right): \mathrm{C}, 68.66 ; \mathrm{H}, 4.14 ; \mathrm{N}$, 10.26. Found: C, $68.61 ; \mathrm{H}, 4.17 ; \mathrm{N}, 10.28$.

2-(benzo[d]thiazol-2-ylthio)- $N$-(4-(8-methyl-4-(5-methyl-1 $H$ indol-3-yl)-1H-benzo [b][1,4]diazepin-2-yl) phenyl) acetamide (8c)

Yield 73\% (Ethanol); M.P $146-148^{\circ} \mathrm{C}$; IR $(\mathrm{KBr})\left(\lambda\right.$ in $\left.\mathrm{cm}^{-1}\right): 1652$, 2808, 3031, 3089, 3399. ${ }^{1} \mathrm{H}$ NMR (DMSO-d $\left.6+\mathrm{CDCl}_{3}\right)^{\delta}(\mathrm{ppm}): 2.45$ (S, $\left.3 \mathrm{H},-\mathrm{CH}_{3}\right), 2.62\left(\mathrm{~S}, 3 \mathrm{H},-\mathrm{CH}_{3}\right), 4.43\left(\mathrm{~S}, 2 \mathrm{H},-\mathrm{CH}_{2}\right), 7.5-8.2(\mathrm{~m}, 21 \mathrm{H}, 20 \mathrm{Ar}-\mathrm{H}$, diazepine - $\mathrm{NH}), 10.14$ (S, 1H, indole -NH), 11.35 (S, 1H, -NH). MS: m/z $=585[\mathrm{M}]^{+}$. Anal. Calcd for $\mathrm{C}_{34} \mathrm{H}_{27} \mathrm{~N}_{5} \mathrm{OS}_{2}$ 585): C, 69.72; H, 4.65; N, 11.96 . Found: C, 69.71; H, 4.68; N, 11.99.

2-(benzo[d]thiazol-2-ylthio)- $N$-(4-(4-(5-bromo- $1 H$-indol-3-yl)-8methyl-1 $H$-benzo[b][1,4]diazepin-2-yl) phenyl) acetamide (8d)

Yield 64\% (Ethanol); M.P 196-198 ${ }^{\circ}$; IR (KBr) $\left(\lambda_{\max }\right.$ in $\left.\mathrm{cm}^{-1}\right): 1671$, 2913, 3094, 3121, 3441, 786. ${ }^{1} \mathrm{H}$ NMR (DMSO- $\left.\mathrm{d}_{6}+\mathrm{CDCl}_{3}\right)^{\delta}(\mathrm{ppm}): 2.4(\mathrm{~S}$, $\left.3 \mathrm{H},-\mathrm{CH}_{3}\right), 4.27\left(\mathrm{~S}, 2 \mathrm{H},-\mathrm{CH}_{2}\right), 7.6-8.6(\mathrm{~m}, 17 \mathrm{H}, 16 \mathrm{Ar}-\mathrm{H}$, diazepine $-\mathrm{NH})$, 10.6 (S, 1H, indole -NH), 11.56 (S, 1H, -NH). MS: $\mathrm{m} / \mathrm{z}=649[\mathrm{M}]^{+}, 651$ $[\mathrm{M}+2]^{+}(1: 1)$. Anal. Calcd for $\mathrm{C}_{33} \mathrm{H}_{24} \mathrm{BrN}_{5} \mathrm{OS}_{2}(649)$ : $\mathrm{C}, 60.92 ; \mathrm{H}, 3.72 ; \mathrm{N}$, 10.76. Found: C, 60.95; H, 3.76; N, 10.75 .

\section{BIOLOGICAL ACTIVITIES}

\section{Antimicrobial activity [24]}

The in vitro antimicrobial activity of the synthesized compounds 6ad, 7a-d, 8a-d was carried out against bacterial strains Escherichia coli (MTCC-723), Staphylococcus aureus (ATCC-29513), and Pseudomonas aeruginosa (MTCC-1688) and fungal species, Aspergillus niger (MTCC281), Aspergillus flavus (MTCC-1973), and Aspergillus oryzae (MTCC$3567^{\mathrm{T}}$ ) by cup plate method [25] using nutrient agar and PDA as medium, respectively. The holes of $6 \mathrm{~mm}$ diameter were punched carefully using a sterile cork borer, and these were filled with test solution $(1000 \mu \mathrm{g} / \mathrm{ml}$ in DMF) and DMF used as a control. The plates were incubated at $37^{\circ} \mathrm{C}$ for 24 and $72 \mathrm{~h}$ in case antibacterial and antifungal activity, respectively. The zones of inhibition around the wells were determined, and the averages based on triplicate measurements were recorded.
Antioxidant activity assay

1, 1-Diphenyl-2-picrylhydrazyl (DPPH) radical scavenging activity (RSA)

The free RSA of all the compounds at concentrations of 25, 50, 75, and $100 \mu \mathrm{g} / \mathrm{ml}$ was carried out in the presence of freshly prepared solution of stable free radical DPPH $(0.04 \% \mathrm{w} / \mathrm{v})$ following Hatano's method [25] using 2-tert-butyl-4-methoxyphenol butylated hydroxy anisole, 2-(1,1-dimethylethyl) -1,4-benzenediol 2-tert-butyl hydroquinone and Ascorbic acid as standards. All the test analyses were performed on three replicates, and the results are averaged. The results in percentage are expressed as the ratio of absorption decrease of DPPH in the presence of test compounds and absorption of DPPH in the absence of test compounds at $\lambda 517 \mathrm{~nm}$ on ELICO SL 171 Mini Spec, spectrophotometer. The percentage scavenging activity of the DPPH free radical was measured using the following equation:

$$
\% \text { of DPPH RSA }=\frac{\text { Absorbance of control-Absorbance of sample }}{\text { Absorbance of control }} \times 100
$$

The results are shown in Fig. 1.

\section{Ferric ions $\left(\mathrm{Fe}^{3+}\right)$ reducing antioxidant power (FRAP)}

The FRAP of the synthesized compounds were determined according to literature method [26]. Different concentrations of samples (25, 50,75 , and $100 \mu \mathrm{g} / \mathrm{ml}$ ) in DMSO (1 ml) were mixed with phosphate buffer $(2.5 \mathrm{ml}, 0.2 \mathrm{M}, \mathrm{pH}=6.6)$ and potassium ferricyanide $(2.5 \mathrm{ml}$, $1 \%$ ). The mixture was incubated at $50^{\circ} \mathrm{C}$ for $20 \mathrm{~min}$. After which a portion of trichloroacetic acid $(2.5 \mathrm{ml}, 10 \%)$ was added to the mixture and centrifuged for $10 \mathrm{~min}$, at $1000 \mathrm{Xg}$. The upper layer of solution $(2.5 \mathrm{ml})$ was mixed with distilled water $(2.5 \mathrm{ml})$ and ferric chloride $(0.5 \mathrm{ml}, 0.1 \%)$. Then, absorbance at $\lambda 700 \mathrm{~nm}$ was measured in a spectrophotometer. The higher absorbance of the reaction mixture indicated greater reducing power. The results are shown in Fig. 2.

\section{Ferrous $\left(\mathrm{Fe}^{2+}\right)$ metal ion chelating activity}

The chelating activity of $\mathrm{Fe}^{2+}$ ion of synthesized compounds was estimated by following reported method [27]. The test samples (25, $50,75$, and $100 \mu \mathrm{g} / \mathrm{ml})$ in ethanolic solution $(0.4 \mathrm{ml})$ were added to a solution of $\mathrm{FeCl}_{2}(0.05 \mathrm{ml}, 2 \mathrm{mmol})$. The reaction was initiated by the addition of ferrozine $(0.2 \mathrm{ml}, 5 \mathrm{mmol})$ and the total volume was adjusted to $4 \mathrm{ml}$ with ethanol. Ferrozine reacted with the divalent iron form stable magenta complex species that were very soluble in water. The mixture was shaken vigorously and kept at room temperature for $10 \mathrm{~min}$. Then, the absorbance of the solution was measured spectrophotometrically at $\lambda 562 \mathrm{~nm}$. All test analyses were run in triplicate and averaged. The percentage of inhibition of the ferrozine $\mathrm{Fe}^{2+}$ complex formations was calculated using the following formula:

$$
\% \text { of ferrousion chelating }=\frac{\begin{array}{l}
\text { Absorbance of control- } \\
\text { Absorbance of sample }
\end{array}}{\text { Absorbance of control }} \times 100
$$

The results are shown in Fig. 3.

\section{RESULTS AND DISCUSSION}

\section{Chemistry}

In the present investigation, 4-aminoacetophenone (1) was reacted with chloroacetyl chloride to form an intermediate $N$-(4-acetylphenyl)-2chloroacetamide (2), which on reaction with 2-mercatobenzimidazole, 2-mercapto-5-methoxy benzimidazole and 2-mercapto benzothiazole, resulted in the formation of 2-(1H-benzo[d]imidazole-2-ylthio) $\mathrm{N}$-(4acetylphenyl) acetamide (3), $N$-(4-acetylphenyl)-2-((5-methoxy- $1 H$ benzo[d]imidazol-2-yl) thio) acetamide (4) and $N$-(4-acetylphenyl)-2(benzo[d]thiazol-2-ylthio) acetamide (5), respectively, by following the literature method [22]. 


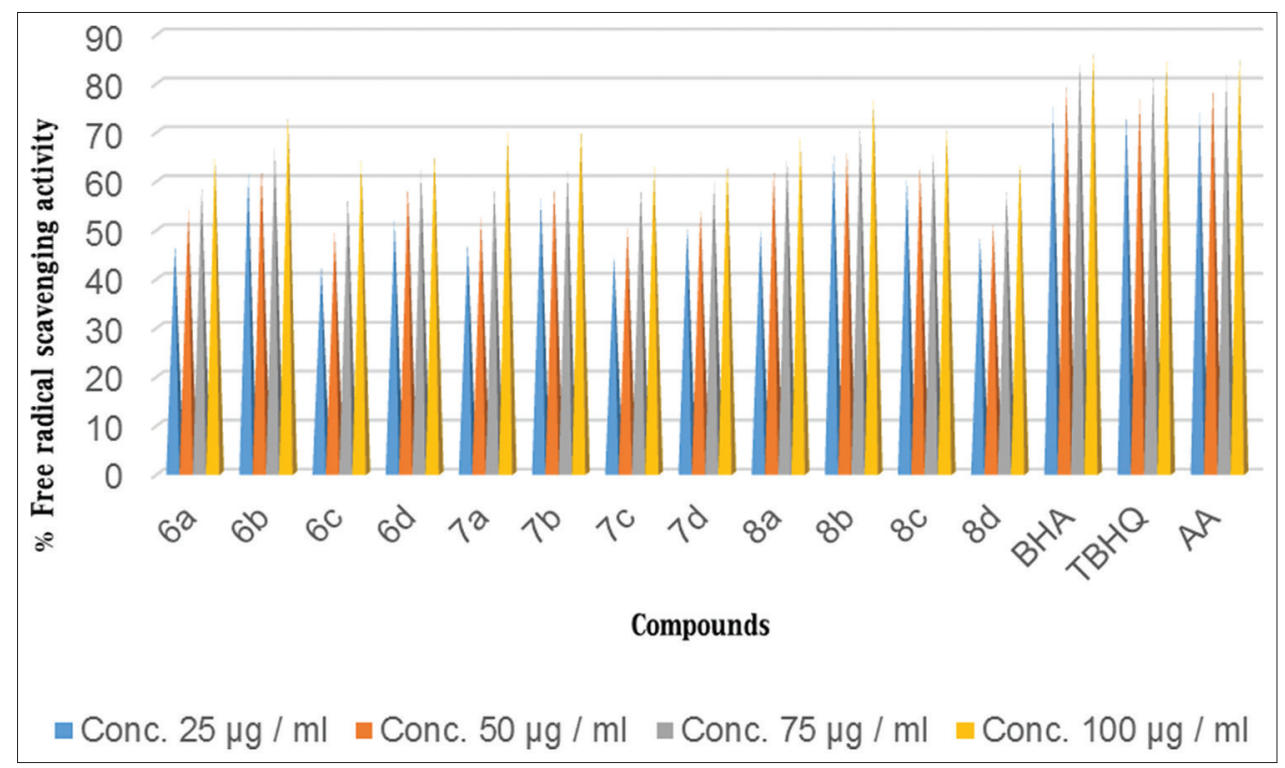

Fig. 1 DPPH radical scavenging activity of compounds 6a-d, 7a-d and 8a-d.

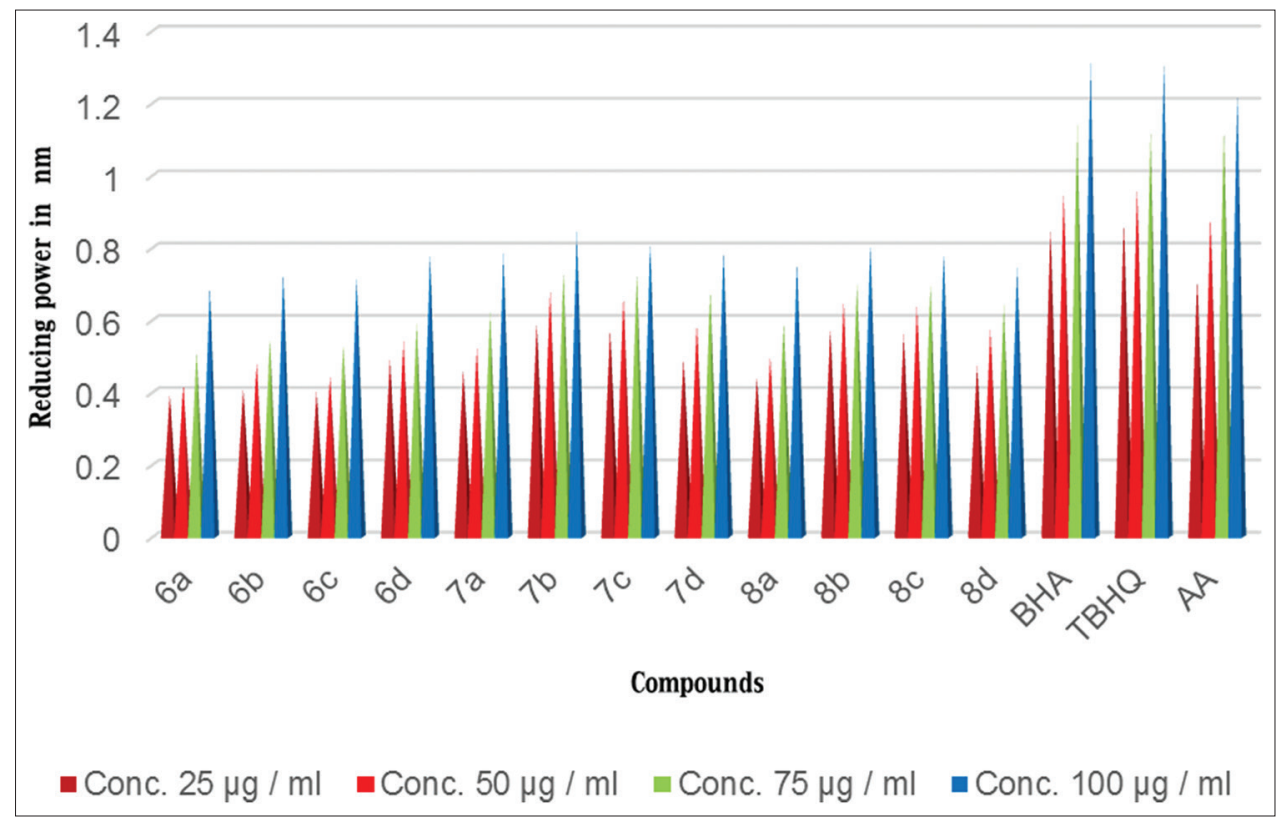

Fig. 2 Reducing Power activity of compounds 6a-d, 7a-d and 8a-d

Compounds 3,4 , and 5 on Claisen-Schmidt condensation with various 2,5-disubstituted indole-3-carboxaldehydes were refluxed in ethanol in the presence of piperidine for $4 \mathrm{~h}$. After $4 \mathrm{~h}$ substituted orthophenylenediamine and catalytic amount of acetic acid was added to reaction mixture and was further refluxed $(7-8 \mathrm{~h})$ to yield the products 2-((1H-benzo[d]imidazol-2-yl) thio)- $N$-(4-(4-(1H-indol-3-yl)-8methyl-1H-benzo[b][1,4]diazepin-2-yl) phenyl) acetamide 6a-d, $N$-(4(4-(1H-indol-3-yl)-8-methyl-1H-benzo[b][1,4]diazepin-2-yl) phenyl)2-((5-methoxy-1H-benzo[d]imidazol-2-yl) thio) acetamide $7 \mathrm{a}-\mathrm{d}$ and $N$-(4-(4-(1H-indol-3-yl)-8-methyl-1H-benzo[b][1,4]diazepin-2-yl) phenyl)-2-(benzo[d] thiazol -2-ylthio) acetamide 8a-d, respectively. The structures of all the novel compounds were confirmed by IR, ${ }^{1} \mathrm{H}$ NMR, and mass spectral studies and elemental data. The synthetic approach is outlined in Scheme 1.

The physical data of the compounds are presented in Table 1. The structures of the compounds were confirmed by IR, ${ }^{1} \mathrm{H}$ NMR, mass spectral studies and elemental data. The IR spectrum of 6 a exhibited absorption band at $3409 \mathrm{~cm}^{-1}, 3318 \mathrm{~cm}^{-1}, 3110 \mathrm{~cm}^{-1}$, and $3098 \mathrm{~cm}^{-1}$ for NH stretching frequency of indole, benzimidazole, amide, and diazepine, respectively. The absorption band at $1673 \mathrm{~cm}^{-1}$ corresponds to $\mathrm{C}=0$ stretching of amide. In the ${ }^{1} \mathrm{HNMR}$ spectrum, the compound $6 \mathrm{a}$ showed a singlet peaks at $12.27,11.2$, and $10.1 \mathrm{ppm}$ ascribed to $\mathrm{NH}$ protons of benzimidazole, amide, and indole, respectively. In addition to this, 17 aromatic protons and one proton of diazepine $\mathrm{NH}$ resonated as a multiplet in the region 7.8-8.2 ppm. The singlet at $4.4 \mathrm{ppm}$ and $2.4 \mathrm{ppm}$ is due to the two protons of methylene group and three protons of methyl group, respectively. Further, the mass spectrum of 6 a showed a molecular ion peak $\mathrm{M}^{+}$at $\mathrm{m} / \mathrm{z} 554$, which confirms its molecular weight and is in good agreement with nitrogen rule.

\section{Antimicrobial activity}

The analysis of antibacterial screening (Table 2) revealed that all compounds tested have moderate to high antibacterial activity as compared to the standard drug streptomycin. Compounds $6 \mathrm{~d}, 7 \mathrm{~b}-\mathrm{d}$, and $8 \mathrm{~b}-\mathrm{d}$ have showed excellent antibacterial activity against the tested microorganism S. aureus (ATCC-29513). Compounds 6b, 6d, 7a-d, and 8a-d have exhibited good activity against E. coli (MTCC-723) whereas 


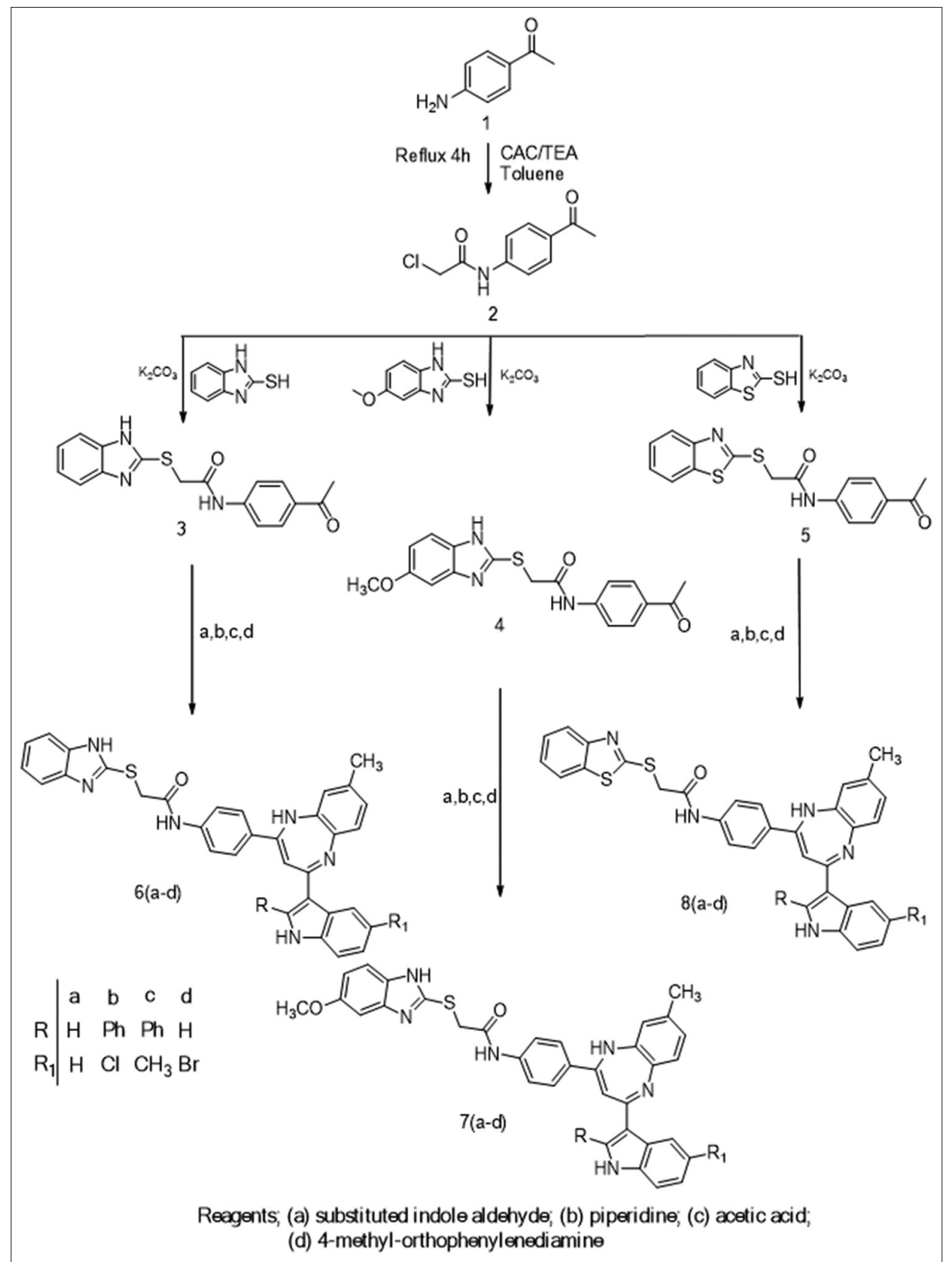

Scheme 1: Synthesis of compounds 3, 4, 5, 6a-d, 7a-d, and 8a-d

Table 1: Physical constant of all the synthesized compounds 3, 4 5, and 6a-d, 7a-d, 8a-d

\begin{tabular}{llllll}
\hline Sample code & $\mathbf{R}$ & $\mathbf{R}^{\mathbf{1}}$ & M. For. & M. Wt. & M. Pt. ${ }^{\circ} \mathbf{C}$ \\
\hline 3 & - & - & $\mathrm{C}_{17} \mathrm{H}_{15} \mathrm{~N}_{3} \mathrm{O}_{2} \mathrm{~S}$ & 325 & 210 \\
4 & - & - & $\mathrm{C}_{18} \mathrm{H}_{17} \mathrm{~N}_{3} \mathrm{O}_{3} \mathrm{~S}$ & 355 & 152 \\
5 & - & - & $\mathrm{C}_{17} \mathrm{H}_{14} \mathrm{~N}_{2} \mathrm{O}_{2} \mathrm{~S}_{2}$ & 342 & 130 \\
$6 \mathrm{a}$ & $\mathrm{H}$ & $\mathrm{H}$ & $\mathrm{C}_{33} \mathrm{H}_{26} \mathrm{~N}_{6} \mathrm{O}_{5}$ & 554 & 176 \\
$6 \mathrm{~b}$ & $\mathrm{Ph}$ & $\mathrm{Cl}$ & $\mathrm{C}_{39} \mathrm{H}_{29} \mathrm{ClN}_{6} \mathrm{OS}$ & 664 & 144 \\
$6 \mathrm{c}$ & $\mathrm{Ph}$ & $\mathrm{CH}_{3}$ & $\mathrm{C}_{40} \mathrm{H}_{32} \mathrm{~N}_{6} \mathrm{OS}$ & 644 & 154 \\
$6 \mathrm{~d}$ & $\mathrm{H}$ & $\mathrm{Br}$ & $\mathrm{C}_{33} \mathrm{H}_{25} \mathrm{BrN}_{6} \mathrm{OS}$ & 632 & 210 \\
$7 \mathrm{a}$ & $\mathrm{H}$ & $\mathrm{H}$ & $\mathrm{C}_{34} \mathrm{H}_{28} \mathrm{~N}_{6} \mathrm{O}_{2} \mathrm{~S}$ & 584 & 160 \\
$7 \mathrm{~b}$ & $\mathrm{Ph}$ & $\mathrm{Cl}$ & $\mathrm{C}_{40} \mathrm{H}_{31} \mathrm{ClN}_{6} \mathrm{O}_{2} \mathrm{~S}$ & 694 & 188 \\
$7 \mathrm{c}$ & $\mathrm{Ph}$ & $\mathrm{CH}$ & $\mathrm{C}_{41} \mathrm{H}_{34} \mathrm{~N}_{6} \mathrm{O}_{2} \mathrm{~S}$ & 674 & 148 \\
$7 \mathrm{~d}$ & $\mathrm{H}$ & $\mathrm{Br}$ & $\mathrm{C}_{34} \mathrm{H}_{27} \mathrm{BrN}_{6} \mathrm{O}_{2} \mathrm{~S}$ & 662 & 188 \\
$8 \mathrm{a}$ & $\mathrm{H}$ & $\mathrm{H}$ & $\mathrm{C}_{33} \mathrm{H}_{25} \mathrm{~N}_{5} \mathrm{OS}_{2}$ & 571 & 134 \\
$8 \mathrm{~b}$ & $\mathrm{Ph}$ & $\mathrm{Cl}$ & $\mathrm{C}_{39} \mathrm{H}_{28} \mathrm{ClN}_{5} \mathrm{OS}_{2}$ & 681 & 178 \\
$8 \mathrm{c}$ & $\mathrm{Ph}$ & $\mathrm{CH}$ & $\mathrm{C}_{34} \mathrm{H}_{27} \mathrm{~N}_{5} \mathrm{OS}_{2}$ & 585 & 146 \\
$8 \mathrm{~d}$ & $\mathrm{H}$ & $\mathrm{Br}$ & $\mathrm{C}_{33} \mathrm{H}_{24} \mathrm{BrN}_{5} \mathrm{OS}_{2}$ & 649 & 196 \\
\hline
\end{tabular}

M. for: Molecular formula, M. wt.: Molecular weight, M. pt.: Melting point the compounds $6 \mathrm{~b}, 6 \mathrm{~d}, 7 \mathrm{a}-\mathrm{d}$, and 8a-d displayed good activity against P. aeruginosa (MTCC-1688).

The antifungal activity results (Table 3 ) discovered that all the synthesized compounds have moderate to high antifungal activity as compared to the standard drug fluconazole. Compounds $6 \mathrm{c}-\mathrm{d}, 7 \mathrm{~b}-\mathrm{c}$, and 8b-d have revealed good activity against A. niger (MTCC-281). Compound 6a-b, 7a-c, and 8b-d showed good activity against $A$. flavus (MTCC-1782) whereas the compounds 6a, 7b-c, and 8b-c have profound activity against $A$. oryzae (MTCC-3567T).

The rest of the compounds was either less or moderately active against the bacterial or fungal strains.

\section{Antioxidant activities}

DPPH RSA

In vitro method of scavenging of the stable DPPH radical is extensively used to evaluate the antioxidant activity in less time than other methods. DPPH is a stable free radical that can accept hydrogen radical 


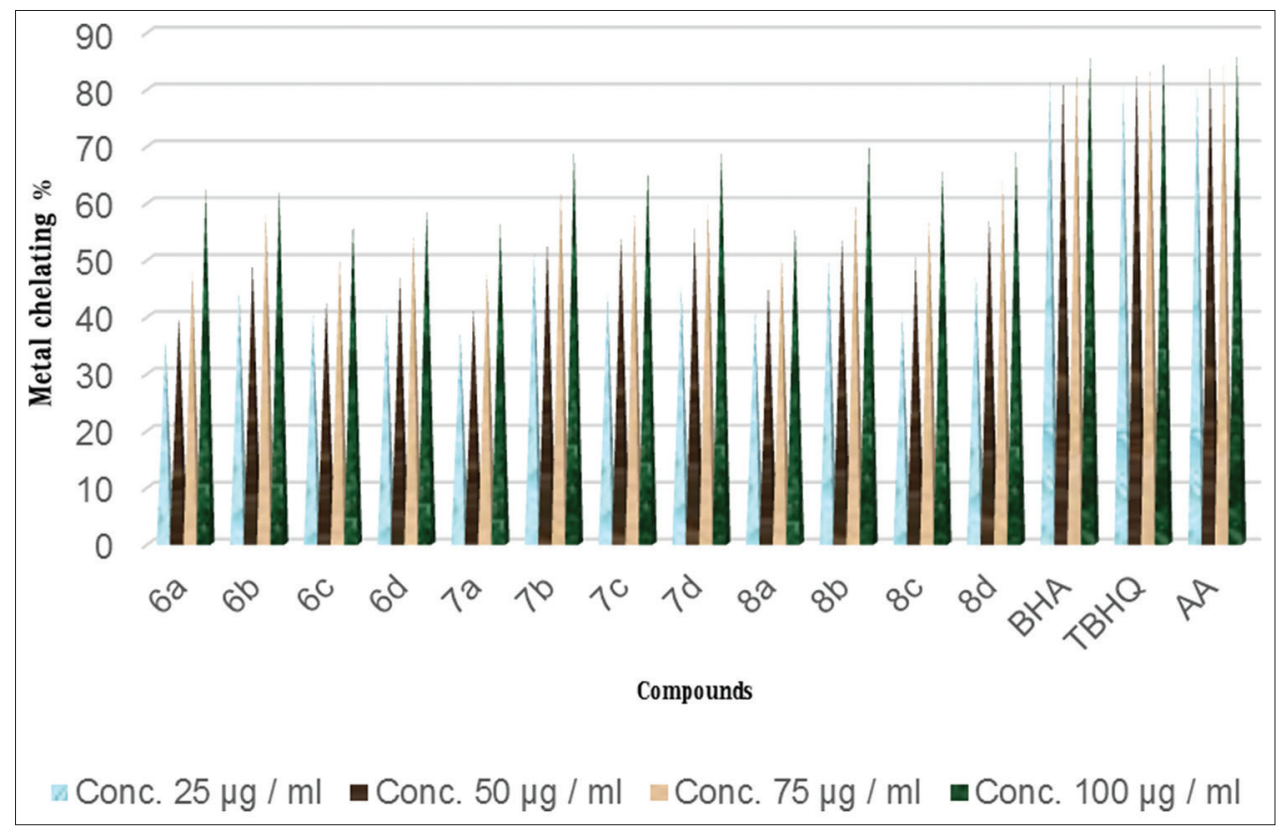

Fig. 3 Metal chelating activity of compounds 6a-d, 7a-d and 8a-d

Table 2: Antibacterial activity, size of inhibition zone (mm) formed at different concentrations $(1000,500,250$, and $125 \mu \mathrm{g} / \mathrm{ml})$ of synthesized compounds $6 \mathrm{a}-\mathrm{d}, 7 \mathrm{a}-\mathrm{d}$, and $8 \mathrm{a}-\mathrm{d}$

\begin{tabular}{|c|c|c|c|c|c|c|c|c|c|c|c|c|}
\hline \multirow[t]{3}{*}{ Compound } & \multicolumn{12}{|c|}{ Zone of inhibition in $\mathrm{mm}$} \\
\hline & \multicolumn{4}{|c|}{ S. aureus } & \multicolumn{4}{|l|}{ E. coli } & \multicolumn{4}{|c|}{ P. aeruginosa } \\
\hline & 1000 & 500 & 250 & 125 & 1000 & 500 & 250 & 125 & 1000 & 500 & 250 & 125 \\
\hline $6 a$ & 11 & 13 & 13 & 12 & 11 & 12 & 12 & 13 & 11 & 12 & 13 & 12 \\
\hline $6 b$ & 15 & 15 & 14 & 15 & 16 & 16 & 15 & 16 & 15 & 15 & 15 & 14 \\
\hline $6 c$ & 13 & 13 & 12 & 11 & 11 & 12 & 13 & 13 & 12 & 13 & 13 & 12 \\
\hline $6 \mathrm{~d}$ & 14 & 15 & 16 & 16 & 15 & 15 & 16 & 15 & 15 & 12 & 14 & 15 \\
\hline $7 b$ & 17 & 17 & 16 & 16 & 16 & 16 & 17 & 17 & 17 & 17 & 16 & 15 \\
\hline $7 c$ & 16 & 15 & 15 & 14 & 14 & 15 & 14 & 15 & 15 & 14 & 14 & 14 \\
\hline $7 d$ & 16 & 15 & 16 & 16 & 16 & 16 & 15 & 15 & 15 & 15 & 15 & 14 \\
\hline $8 a$ & 14 & 14 & 15 & 15 & 14 & 14 & 15 & 15 & 15 & 15 & 14 & 14 \\
\hline $8 b$ & 17 & 17 & 17 & 16 & 16 & 16 & 15 & 15 & 16 & 16 & 16 & 16 \\
\hline $8 c$ & 15 & 15 & 16 & 16 & 15 & 15 & 14 & 14 & 14 & 14 & 14 & 13 \\
\hline $8 d$ & 16 & 16 & 16 & 16 & 15 & 15 & 16 & 15 & 15 & 15 & 14 & 14 \\
\hline Streptomycin & 17 & 17 & 17 & 17 & 17 & 16 & 16 & 16 & 15 & 16 & 16 & 15 \\
\hline
\end{tabular}

Value are expressed as mean (n=3). E. coli: Escherichia coli, S. aureus: Staphylococcus aureus, P. aeruginosa: Pseudomonas aeruginosa

Table 3: Antifungal activity, size of inhibition zone (mm) formed at different concentrations $(1000,500,250$, and $125 \mu \mathrm{g} / \mathrm{ml})$ of synthesized compounds 6a-d, 7a-d, and 8a-d

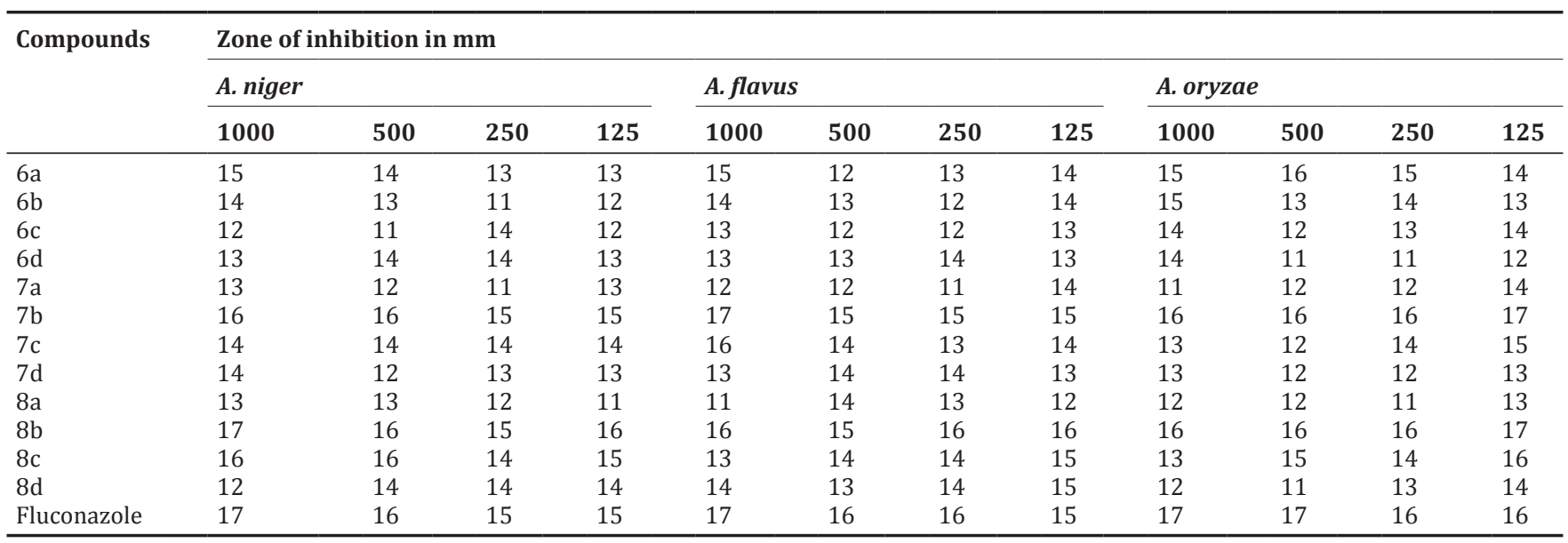

Values are expressed as mean (n=3). A. niger: Aspergillus niger, A. flavus: Aspergillus flavus, A. oryzae: Aspergillus oryzae 
or an electron and must thus be converted to a stable diamagnetic molecule. DPPH has an odd electron and so has a strong absorption band at $517 \mathrm{~nm}$. When this electron becomes paired off, the absorption decreases stoichiometrically with respect to the number of electrons or hydrogen atoms are taken up. The DPPH antioxidant assay measures the hydrogen donating capacity of the molecules under study. When the free radical DPPH is reduced by the sample its color changes from violet to yellow. The results (Fig. 1) suggested that compounds 6b, 8b, and 8c showed promising RSA at all concentrations. Compounds $6 \mathrm{~d}, 7 \mathrm{~b}, 7 \mathrm{~d}$, and 8 a were found to enhance the RSA 51.77, 56.21, 50.59, and 50.00\%, respectively, at Conc. $25 \mu \mathrm{g} / \mathrm{ml}$. Compound 8a showed good activity, i.e., $62.13 \%$ at conc. $50 \mu \mathrm{g} / \mathrm{ml}$ and 64.79 at Conc. $75 \mu \mathrm{g} / \mathrm{ml}$. Compounds $7 \mathrm{a}$ and $7 \mathrm{~b}$ showed promising activity, i.e., 69.82 and $71.00 \%$, respectively, at conc. $100 \mu \mathrm{g} / \mathrm{ml}$. The rest of the compounds was found to possess less to moderate activity.

\section{FRAP}

The FRAP results (Fig. 2) suggested that, the compounds $6 \mathrm{~d}, 7 \mathrm{a}-\mathrm{d}$, and 8a-c showed good absorbance 0.782, 0.783, 0.841, 0.811, 0.793, $0.761,0.809$, and $0.786 \mathrm{~nm}$, respectively, at concentration $100 \mu \mathrm{g} / \mathrm{ml}$, indicating that these compounds have good FRAP at concentrations of $100 \mu \mathrm{g} / \mathrm{ml}$. In other words, these compounds showed the ability of electron donor to scavenge free radicals. The rest of the compounds showed lower absorbance as related to the standards. The higher the absorbance of the compounds indicated greater reducing power.

\section{$\mathrm{Fe}^{2+}$ metal ion chelating activity}

$\mathrm{Fe}^{2+}$ metal ion chelating activity results (Fig. 3) revealed that synthesized compounds obstructed the formation of $\mathrm{Fe}^{2+}$ and ferrozine complex. Compounds 7b-d and 8b-d exhibited (69.15, 66.04, 69.15, $71.02,66.04$, and $68.84 \%$, respectively) good metal chelating activity at concentration of $100 \mu \mathrm{g} / \mathrm{ml}$. Highest metal chelating activity of these compounds indicates that these compounds are able to capture $\mathrm{Fe}^{2+}$ ion before ferrozine.

This might be the reason for the higher metal chelating activity. The rest of the compounds showed reasonable to less activity when compared with the standard drugs.

\section{CONCLUSION}

The title compound of benzodiazepine derivatives attached with benzimidazole/benzothiazole and indole moieties is synthesized and characterized using spectral and analytical data. All the compounds have been subjected for antimicrobial, antifungal, and antioxidant screening. We have found that compounds are active toward antibacterial and antifungal strains. Few compounds gave better antioxidant activity compared to the standard. These studies may promote further extension of the benzodiazepine derivatives bearing benzimidazole/ benzothiazole and indole moieties, which may lead to compounds with effective antioxidant and antimicrobial activities.

\section{ACKNOWLEDGMENTS}

The authors sincerely acknowledge UGC-BSR, No.F.25-1/2013-14 (BSR) /No.F.7-226/2009 (BSR) dated November 19, 2014, New Delhi (India), for financial support. The authors are thankful to the Chairman, Department of Chemistry, Gulbarga University, Kalaburagi, for providing laboratory facilities to the Chairman, Department of Microbiology, Gulbarga University, Kalaburagi, for providing facilities to carry out antimicrobial activity and also thankful to the Director, CIL, Punjab University, Chandigarh and to the Director, Indian Institute Of Technology, Madras, Chennai, for providing spectral data. Authors are also thankful for BioGenics Research and Training Centre in Biotechnology, Hubli, for biological studies.

\section{REFERENCES}

1. Mallinath ML. One pot method for green synthesis of 1 , 5-benzodiazepines. Der Pharma Chem 2011;3(2):273-6.
2. Baun DJ, Pallos FM, Baker DR. US Patent 3,978,227, 1976. Chem Abstr 1977;86:5498d.

3. Naraboli BS, Biradar JS. Synthesis, characterization and biological evaluation of indole derivatives bearing benzimidazole/benzothiazole moiety. Int J Pharm Pharm Sci 2017;9(8):128-38.

4. Sandra CM, Eduardo CC, Simon HO, Teresa RA, Antonio NC, Lijanova IV, et al. Anticancer activity and anti-inflammatory studies of 5-aryl-1, 4-benzodiazepine derivatives. Anticancer Agents Med Chem 2012;12(6):611-8

5. Henderson EA, Alber DG, Baxter RC, Bithell SK, Budworth J, Carter MC, et al. 1,4-benzodiazepines as inhibitors of respiratory syncytial virus. The identification of a clinical candidate. J Med Chem 2007;50(7):1685-92.

6. Griffin CE $3^{\text {rd }}$, Kaye AM, Bueno FR, Kaye AD. Benzodiazepine pharmacology and central nervous system-mediated effects. Ochsner J 2013;13(2):214-23.

7. Sundberg RJ. The Chemistry of Indoles. New York: Academic Press; 1996.

8. Sayed MT, Hamdy NA, Osman DA, Ahmed KM. Indole as anti-cancer agents. Adv Mod Oncol Res 2015;1(1):20-35.

9. Biradar JS, Sasidhar BS, Parveen R. Synthesis, antioxidant and DNA cleavage activities of novel indole derivatives. Eur J Med Chem 2010;45(9):4074-8.

10. Abdel RF. Synthesis of some new indole derivatives containing pyrazoles with potential antitumor activity. ARKIVOC 2010;11:177-87.

11. Ragno R, Artico M, De Martino G, La Regina G, Coluccia A, Di Pasquali A, et al. Docking and 3-D QSAR studies on indolyl aryl sulfones. Binding mode exploration at the HIV-1 reverse transcriptase non-nucleoside binding site and design of highly active $\mathrm{N}-(2-$ hydroxyethyl) carboxamide and $\mathrm{N}$-(2-hydroxyethyl) carbohydrazide derivatives. J Med Chem 2005;48(1):213-23.

12. Sabrina RA, Biplab KD, Shahadat H, Uttom K, Abu SS. Synthesis and antioxidant activity of 2-substituted-5-nitro benzimidazole derivatives. Int J Pharm Pharm Sci 2017;9(1):308-10.

13. Chen G, Liu Z, Zhang Y, Shan X, Jiang L, Zhao Y, et al. Synthesis and anti-inflammatory evaluation of novel benzimidazole and imidazopyridine derivatives. ACS Med Chem Lett 2012;4(1):69-74.

14. Radha Y, Manjula A, Madhava B, Vittalrao B. Synthesis and biological activity of novel benzimidazoles. Indian J Chem 2011;50B:1762-73.

15. Zou R, Ayres KR, Drach JC, Townsend LB. Synthesis and antiviral evaluation of certain disubstituted benz imidazole rib nucleosides. J Med Chem 1996;39(18):3477-82.

16. Shingalapur RV, Hosamani KM, Keri RS, Hugar MH. Derivatives of benzimidazole pharmacophore: Synthesis, anticonvulsant, antidiuretic and DNA cleavage studies. Eur J Med Chem 2010;45(5):1753-9.

17. Vinodkumar R, Vaidya SD, Siva Kumar BV, Bhise UN, Bhirud SB, Mashelkar UC. Synthesis, anti-bacterial, anti-asthmatic and anti-diabetic activities of novel N-substituted-2-(4-phenylethynylphenyl)-1H-benzimidazoles and $\mathrm{N}$-substituted 2[4-(4,4-dimethylthiochroman-6-yl-ethynyl)-phenyl)-1H-benzimidazoles. Eur J Med Chem 2008;43(5):986-95.

18. Bradshaw TD, Westwell AD. The development of the antitumour benzothiazole prodrug, Phortress, as a clinical candidate. Curr Med Chem 2004;11(8):1009-21.

19. Bhupendra M, Rahul VP, Young-SK, Doo HK. Evaluation of the biological potencies of newly synthesized bebeerine derivatives bearing benzothiazole moieties with substituted functionalities. J Saudi Chem Soc 2017;21:210-19.

20. Jitender KM, Himesh S, Singhai AK. Synthesis, characterization and evaluation for antifungal activity of substituted diaryl imidazo [2, 1, b]-benzothiazole. J Pharm Res 2013;7(1):39-46.

21. Suresh M, Sridevi G, Nuthangi S, Palakondu L, Sreekanth, Jonnalagadda B. Synthesis, antibacterial and antifungal activity of novel benzothiazole pyrimidine derivatives. Arab J Chem 2016;9:681-7.

22. Sunil K, Rathore DS, Gopal G, Kapil K, Rahul S, Sanjeev KS. Synthesis and evaluation of some benzothiazole derivatives as antidiabetic agents. Int J Pharm Pharm Sci 2016;9(2):60-8.

23. Kalpesh P, Deepkumar J. Antibacterial and antifungal screening of newly synthesized benzimidazole-clubbed chalcone derivatives. Med Chem Res 2013;22:3688-97.

24. National Committee for Clinical Laboratory Standards (NCCLS). Wayne, Pennsylvania 19087-1898, USA. Performance Standards for Antimicrobial Susceptibility Testing: $20^{\text {th }}$ Informational Supplement 2002, M100-S12 [M7]

25. Hatano T, Kagawa H, Yasuhara T, Okuda T. Two new flavonoids and 
other constituents in licorice root: Their relative astringency and radical scavenging effects. Chem Pharm Bull (Tokyo)1988;36(6):2090-7.

26. Oyaizu M. Studies on products of browning reactions: Ant oxidative activities of products of browning reaction prepared from glucosamine. Jpn Nut 1986;44:307-15.

27. Dinis TC, Maderia VM, Almeida LM. Action of phenolic derivatives (acetaminophen, salicylate, and 5-aminosalicylate) as inhibitors of membrane lipid peroxidation and as peroxyl radical scavengers. Arch Biochem Biophys 1994;315(1):161-9.

28. Pushpa H, Naraboli BS, Biradar JS. Synthesis, characterization, and biological activity of novel n-phenylpropyl-3-substituted indoline-2one derivatives. Int J Pharm Pharm Sci 2017;9(10):165-70. 